\title{
EXERGETIC EFFICIENCY ANALYSIS OF A COMBINED POWER PLANT OF A CONTAINER SHIP
}

\begin{abstract}
Y. Durmusoglu1, ${ }^{1, *}$, G.Kocak ${ }^{1}$
ABSTRACT

Energy problems in the world require more efficient use of energy. Thus, in recent years there has been a significant increase in scientific studies on energy efficiency. Approximately $80 \%$ of world trade is carried by sea. Therefore, transportation of such a big volume requires large-scale energy consumption. For this reason, energy efficiency is very important in the maritime sector. The International Maritime Organization (IMO) which is the authority on maritime transport in the world executes obligations and recommendations for energy efficiency and environmental pollution issues. An important method of scientifically measuring energy efficiency is exergy analysis. It is observed that the performance analysis by exergy method is not applied to the shipping sector sufficiently, so this paper is tried to fill this gap in maritime area. In this article, the performance of the combined power system of a container ship is analyzed by the exergy method. According to the obtained results, the total exergy efficiency of the system is observed to be $49 \%$.
\end{abstract}

\section{Keywords: Shipping, Energy Efficiency, Exergy, Combined Power System}

\section{INTRODUCTION}

Ships are floating power plants. They produce energy and exploit this energy mainly for powering the propulsion systems during their port-to-port voyages. Moreover, ships require electricity for maneuvering, hotels and operation of all electrical and electronic equipment. A main engine and small size generators that are using fossil fuels supply all energy requirements of a ship. Besides there are also some systems producing electricity from turbo generator powered using the waste heat and/or a shaft generator. There are various auxiliary machinery on board ship powered by electrical energy. Taking into consideration all these facts, cost of the energy production on ships may reach high levels annually. For this reason, usage of energy efficiently on ships should be considered seriously. The International Maritime Organization (IMO), which is the authority on maritime transport in the world, executes obligations and recommendations for energy efficiency and environmental pollution issues. The energy efficiency requirements were adopted as amendments to MARPOL Annex VI in 2011 and entered into force on 2013 [1]. Therefore, the shipping companies should obey the rules and regulations declared by IMO.

One of the popular methods for evaluating energy efficiency is exergy analysis which is based on second law of thermodynamics. The most prominent feature of the exergy analysis is its capability to analyze individual components of the system separately. Thus, it is possible to monitor the location and level of the irreversibility of the components. Combined power systems are one of the methods used to increase energy efficiency. These systems consist of two different power cycles, the primary and secondary cycles. On board ships, these combinations are often confronted as Diesel and Rankine power cycles. In our study a turbo-charged (T/C) diesel engine combined with a turbo generator $(\mathrm{T} / \mathrm{G})$ is inspected which is explained elaborately in next section.

Feng et al. (1998) defined a new parameter to evaluate the efficiency of a cogeneration power plant which is called cogeneration efficiency. In this study the authors also carried out an exergy efficiency and make comparison with their parameter. They show that the compared results are very similar [2]. Franco and Russo (2002), studied exergetic efficiency of a combined cycle (CC) plant which consists of a Brayton cycle and a Rankine cycle. They could increase the overall plant efficiency to $60 \%$ which is mentioned as the goal of the sector by authors [3]. Yilmaz, T. (2004) made an optimization of waste heat recovery system and carried out the exergetic performance analysis based on alternative performance criteria [4].

Danov and Gupta (2004), developed computational tools in their studies to investigate the mutual operation between a turbocharged diesel engine and a heat recovery steam generator (HRSG) in combined- cycle power plants [5-6]. Tien et al. (2005) studied a waste heat recovery for generating electricity through a steam turbine on a ship. An iterative mathematical model is proposed utilizing heat transfer laws. They show that the proposed mathematical model is comparable with the experimental results [7]. Ebadi and Bandpy (2005) applied an exergy analysis method to a $116 \mathrm{MW}$ gas turbine plant. They evaluated the effect of change in the turbine inlet 
temperature on the exergetic efficiency and exergy destruction in the plant and confirmed that inlet temperature is crucial for exergy efficiency and exergy destruction [8]. Kamate and Gangavati (2008), analyzed a 20.70 MW cogeneration plant using the exergetic, thermal and fuel saving methods. They achieved $69 \%$ energy utilization factor and 28\% exergetic efficiency [9]. Abusoglu and Kanoglu (2009a, 2009b) studied exergy analysis of a diesel engine powered cogeneration system (DEPC). The authors applied their exergy methodology on a reel plant which has a total installed electricity capacity of 25.3MW, installed in Gaziantep, Turkey. They concluded that the exergy efficiency of the plant is determined to be $40.6 \%$ [10,11].

In the report of MAN Diesel and Turbo (MAN, 2012), it is shown that the possibility to generate an electrical output from the main engine power by utilising exhaust gas energy in a waste heat recovery system is up to $11 \%$ [12]. Saidur et al. (2012) made a review of studies for waste heat recovery from the internal combustion engines (ICE). In this study mainly thermoelectric generators (TEG), organic rankine cycle (ORC), six-stroke cycle IC engines and developments of turbocharger (T/C) technologies are inspected. [13]. Shu et al. (2013) studied a review of waste heat recovery on two-stroke IC engine aboard ships. In their study, they considered basic principles, novel methods, existing designs, theoretical and experimental analyses, economics and feasibility [14]. Grljušić et. al. (2014), inspected a combined heat and power (CHP) production of a Suezmax-size oil tanker that utilizes the low-temperature waste heat energy for all heating and electricity requirements during navigation. They analyzed various configurations for waste heat recovery and observed that a supercritical organic Rankine cycle (ORC) performs maximum efficiency [15]. Modern large diesel engines are about 50\% efficient in utilizing the fuel heat energy and the remainder is lost to the environment as waste heat [16]. Baldi and Gabrielli predicted, based on exergy analysis, an achievable fuel savings of $4-16 \%$ for a medium range tanker by the use of watse heat recovery system (WHRS) [17].

M. H. Seyyedvalilu and et al. (2015) carried out an exergy and exergoeconomic analysis and parametric study of a diesel engine based combined heat and power (CHP) system. In the results, they showed that how influences the heating power, exergetic efficiency, and exergy destruction cost and exergoeconomic factor of the CHP system in all environment temperatures with the cycle design parameters [18]. Benvenuto et al. (2014) studied a system to increase the efficiency of a waste heat recovery system and compared it with a traditional waste heat recovery system which consists of a steam turbine (ST) and exhaust gas turbine (EGT). In this study, the authors designed a system which utilizes heat energy of scavenging air and jacket cooling water to increase feed water temperature. They could increase the efficiency of overall system from 56\% to 57.5\% [19]. Marty et. al. (2016), analyzed a ship power plant on a simulation. They carried out exergy analysis and proposed some solutions to improve efficiency of the system. They mainly propose to replace fresh water generator with a reverse osmoses system and utilize waste heat in an ORC system [20]. Baldi et. al.(2015a and 2015b) studied exergy analysis of a chemical tanker and a cruise ship. They find out that the exergetic value of the exhaust gasses represent the $18 \%$ of the engine power output. Therefore, it is a significant point for energy recovery [21, 22]. A WHRS can utilize the remaining wasted heat for producing mechanical/-electrical power which can then feed the demand for propulsion and auxiliary services at no additional fuel costs and zero associated $\mathrm{CO}_{2}$ emissions [23].

There are many studies of exergy analysis method which are generally applied for shore power plants. However, for marine power plants there are very few studies which are mentioned above. In this study, thermodynamic performance analysis of a 4200 TEU container ship combined power system is carried out based on exergetic approach which is not studied before. The data used for the analysis is obtained from a realistic engine room simulator (ERS) of Kongsberg maritime company. This data is used in the mathematical model of the power system which is modelled in Engineering Equation Solver (EES). By this study, the main power generation of a container ship is analyzed and it is possible to evaluate the exergy efficiency of each component to carry out necessary improvements.

\section{MATERIAL AND METHODS Ship Combined Systems}

In marine power systems, the energy efficiency increase from waste heat can be realized in various ways. Most confronted methods are cogeneration and combined power systems. The combined power system utilizes supplementary waste heat recovery sources for preheating of the feed water that will increase the obtainable steam. Therefore, superheated steam can be produced which is used for electric power production of a marine power plant [16]. Today's power systems overall efficiency can be increased up to $55 \%$ in combined power systems which use waste heat recovery. A sample combined marine power system is shown in Figure 1. In this system, a diesel engine 
is used for primary power production. The waste heat of diesel engine's exhaust gas is recovered by exhaust gas boiler and exhaust gas turbine. Besides, a steam turbine is powered by the superheated steam from the boiler which drives a turbo generator $(\mathrm{T} / \mathrm{G})$. Even more the $\mathrm{T} / \mathrm{G}$ is supported by an exhaust gas turbine.

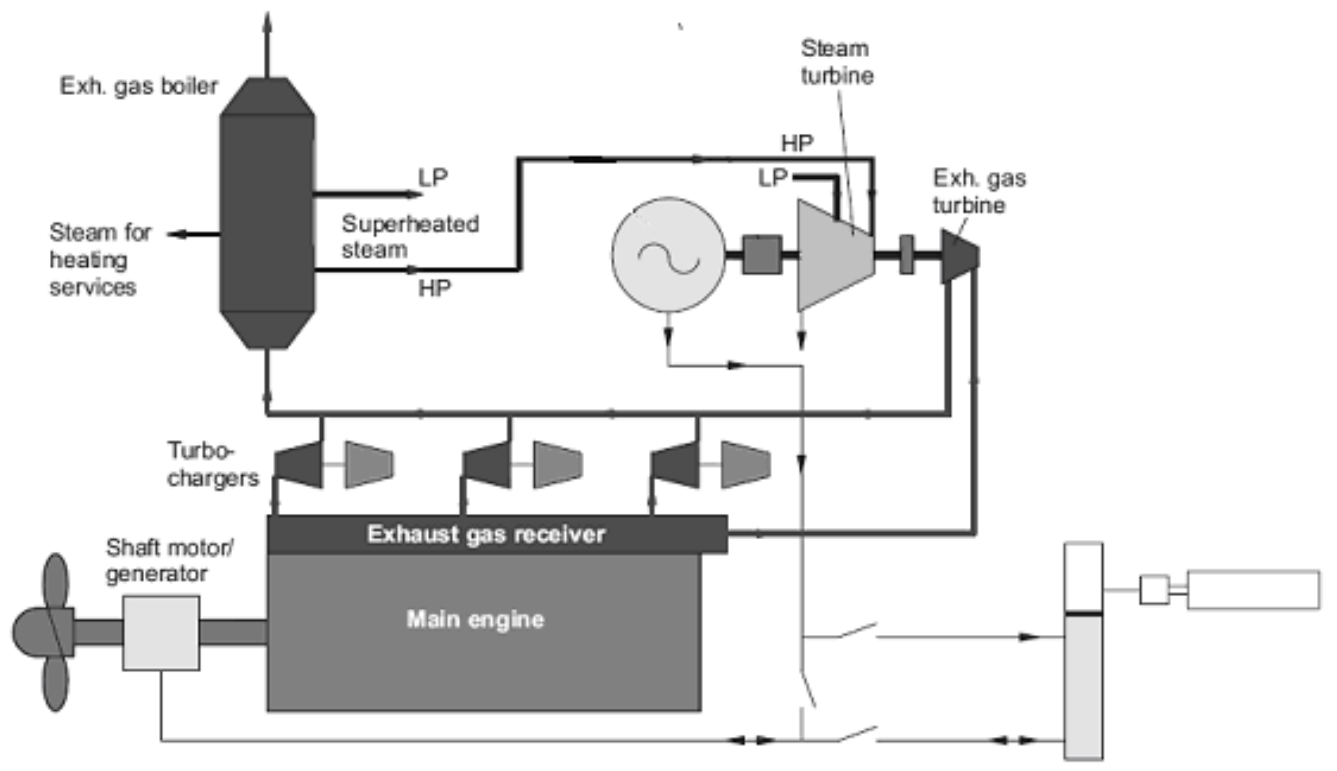

Figure 1. A ship energy efficiency application by MAN B\&W in 2007 [16].

\section{Exergy Analysis}

Exergy is defined as the maximum useful work that can be obtained from a reversible thermodynamic system while the system comes into equilibrium with its environment. The environmental condition is called as dead state condition in which pressure is $\mathrm{P}_{0}$ and temperature is $\mathrm{T}_{0}$. Exergy is a significant tool for measurement of energy efficiency due to possibility of component-based analysis of the system efficiency and irreversibility. The loss of exergy, or irreversibility, provides a generally applicable quantitative measure for inefficiencies [24].

Exergy balances of the power plant should be determined in order to perform the exergy analysis. The exergy balance equation is formed as:

$$
\sum \dot{E}_{Q}-\sum \dot{E}_{\dot{W}}+\sum \dot{E}_{\text {in }}-\sum \dot{E}_{\text {out }}=\dot{E}_{D}
$$

where $\dot{E}_{D}$ is the exergy destruction. The exergy destruction is the irreversible energy called also as anergy. The total exergy ( $\dot{E}$ ) of a system can be shown as follows:

$$
\dot{E}=\dot{m} \cdot e
$$

where $\dot{m}$ is the mass flow rate in $\mathrm{kg} / \mathrm{s}$ and $e$ is the specific exergy in $\mathrm{kJ} / \mathrm{kg}$. The exergies of heat and work are expressed as follows,

$$
\begin{gathered}
\dot{E}_{\dot{Q}}=\dot{Q}\left(1-\frac{T_{0}}{T}\right) \\
\dot{E}_{\dot{W}}=\dot{W}
\end{gathered}
$$

where $\mathrm{T}$ is the temperature of heat source in $K$ and $\mathrm{W}$ is the total work done by the system in $k W$. Substituting Eq.(2-4) in Eq.(1), we obtain: 
Journal of Thermal Engineering, Research Article, Vol. 5, No. 1, Special Issue 9, pp. 1-13, January, 2019

$$
\sum \dot{Q}\left(1-\frac{T_{0}}{T}\right)-\dot{W}+\sum_{i} \dot{m}_{i} e_{i}-\sum_{o} \dot{m}_{o} e_{o}=\dot{E}_{D}
$$

where $e_{i}$ is input specific exergy and $e_{o}$ is output specific exergy. The specific exergy (e) consists of physical exergy $\left(e^{P H}\right)$, chemical exergy $\left(e^{C H}\right)$, potential exergy $\left(e^{P E}\right)$ and kinetic exergy $\left(e^{K E}\right)$. As a general approach, the kinetic and potential exergy are negligible [24]. The physical exergy and the chemical exergy are defined as follows, respectively:

$$
\begin{gathered}
e^{P H}=\left(h-h_{0}\right)-T_{0}\left(s-s_{0}\right) \\
e^{C H}=\sum_{i=1}^{n} X_{i} e_{i}^{C H}+R T_{0} \sum_{i=1}^{n} X_{i} \ln \left(X_{i}\right)
\end{gathered}
$$

where $\mathrm{X}_{\mathrm{i}}$ is the moles of $i^{\text {th }}$ gases and $e_{i}^{C H}$ is the standard chemical exergy of gases and gas mixtures and selected from a table of standard chemical exergies [25]. Therefore, the specific exergy can be expressed as,

$$
e=e^{P H}+e^{C H}
$$

Eq.(8) is not sufficient for calculation of specific exergy of the fuel. Thus, the specific exergy of the fuel is calculated by:

$$
e_{f}=L H V \cdot \phi_{i}
$$

where $\phi_{i}$ is a parameter which depends on different fuel types ( $i=$ solid, fluid, gas) and LHV is the lower heat value of fuel in $\mathrm{kJ} / \mathrm{kg}$. The $\phi_{i}$ is calculated for solid, fluid and gas fuel types by the following experimental equations proposed by Bejan (1996) [26], respectively.

$$
\begin{gathered}
\phi_{s}=1.0437+0.1882 \frac{H}{C}+0.0610 \frac{O}{C}+0.0404 \frac{N}{C} \\
\phi_{f}=1.0401+0.1728 \frac{H}{C}+0.0432 \frac{O}{C}+0.2169 \frac{S}{C}\left(1-2.0628 \frac{H}{C}\right) \\
\phi_{g}=1.033+0.0169 \frac{H}{C}-\frac{0.0698}{C}
\end{gathered}
$$

To analyze the exergetic efficiency of a thermodynamic system it is required to identify the terms product $\left(\dot{E}_{P}\right)$ and fuel $\left(\dot{E}_{F}\right)$. The product is the exergy that contains the benefits obtained while the fuel is the exergy provided for the subsystem through the resources [27]. In the combined power system analyzed in this study, the exergy of propulsion power and electrical power of T/G is product and the exergy of heavy fuel oil is the fuel. Therefore, the exergetic efficiencies of subsystems are calculated by:

$$
\varepsilon=\frac{\dot{E}_{P}}{\dot{E}_{F}}
$$

Eventually, the overall exergetic efficiency of the combined power plant is determined as: 
Journal of Thermal Engineering, Research Article, Vol. 5, No. 1, Special Issue 9, pp. 1-13, January, 2019

$$
\varepsilon_{o s}=\frac{\dot{E}_{P}}{\dot{E}_{F}}=\frac{\dot{W}_{M E}+\dot{W}_{T G}}{\dot{m}_{f} L H V}
$$

where, $m_{f}$ is the mass flow rate of the fuel. There are two exergy destruction ratios which are useful for comparing various components of the same system. These are the rate of exergy destruction ratios $\left(y_{D}\right)$ and $\left(y_{D}{ }^{*}\right)$. First exergy destruction ratio $\left(y_{D}\right)$ is comparison of the exergy destruction in a system component to the fuel provided to the overall system which is formulized as:

$$
y_{D}=\frac{\dot{E}_{D}}{\dot{E}_{F, \text { total }}}
$$

The latter is $\left(y_{D}{ }^{*}\right)$ the comparison of the exergy destruction in a system component to the total exergy destruction rate within the system which is expressed as:

$$
y_{D}^{*}=\frac{\dot{E}_{D}}{\dot{E}_{D, \text { total }}}
$$

\section{Exergy Analysis of the Marine Power Plant}

The ship's engine room is a very complex power system. There are various types of marine power plants. Some ships may have shaft generator system whereas another ship may have turbo generator etc. The plant analyzed in this study is a combined power plant of a container ship with a diesel engine as primary power system and a turbo generator as a secondary power system. The specifications of the container ship are listed in Table 1.

Table 1. Specifications of the container ship

\begin{tabular}{lcc}
\hline Length overall & 295 & $\mathrm{~m}$ \\
TEU & 4200 & - \\
Breadth & 32 & $\mathrm{~m}$ \\
Draught & 12.6 & $\mathrm{~m}$ \\
DWT & 55000 & tons \\
Service speed & 25 & knots \\
\hline
\end{tabular}

The data used for the analysis is obtained from a realistic engine room simulator (ERS) of Kongsberg maritime company while the plant is running at the condition of full speed ahead and full loaded. Then, analyzes is performed by building the mathematical model of the power system with Engineering Equation Solver (EES). The specifications of the marine power plant are listed in Table 2 .

Table 2. Specifications of the power plant.

\begin{tabular}{lcc}
\hline Type & Sulzer 12RTA 84 C & - \\
Bore & 84 & $\mathrm{~cm}$ \\
Stroke & 240 & $\mathrm{~cm}$ \\
Cylinders & 12 & - \\
Engine speed & 102 & rpm (full load) \\
Power & 42.85 & MW (full load) \\
sfoc & 168 & $\mathrm{~g} / \mathrm{kW} . \mathrm{h}$ (full load) \\
FOC & 7.7 & ton/day \\
\hline
\end{tabular}


Journal of Thermal Engineering, Research Article, Vol. 5, No. 1, Special Issue 9, pp. 1-13, January, 2019

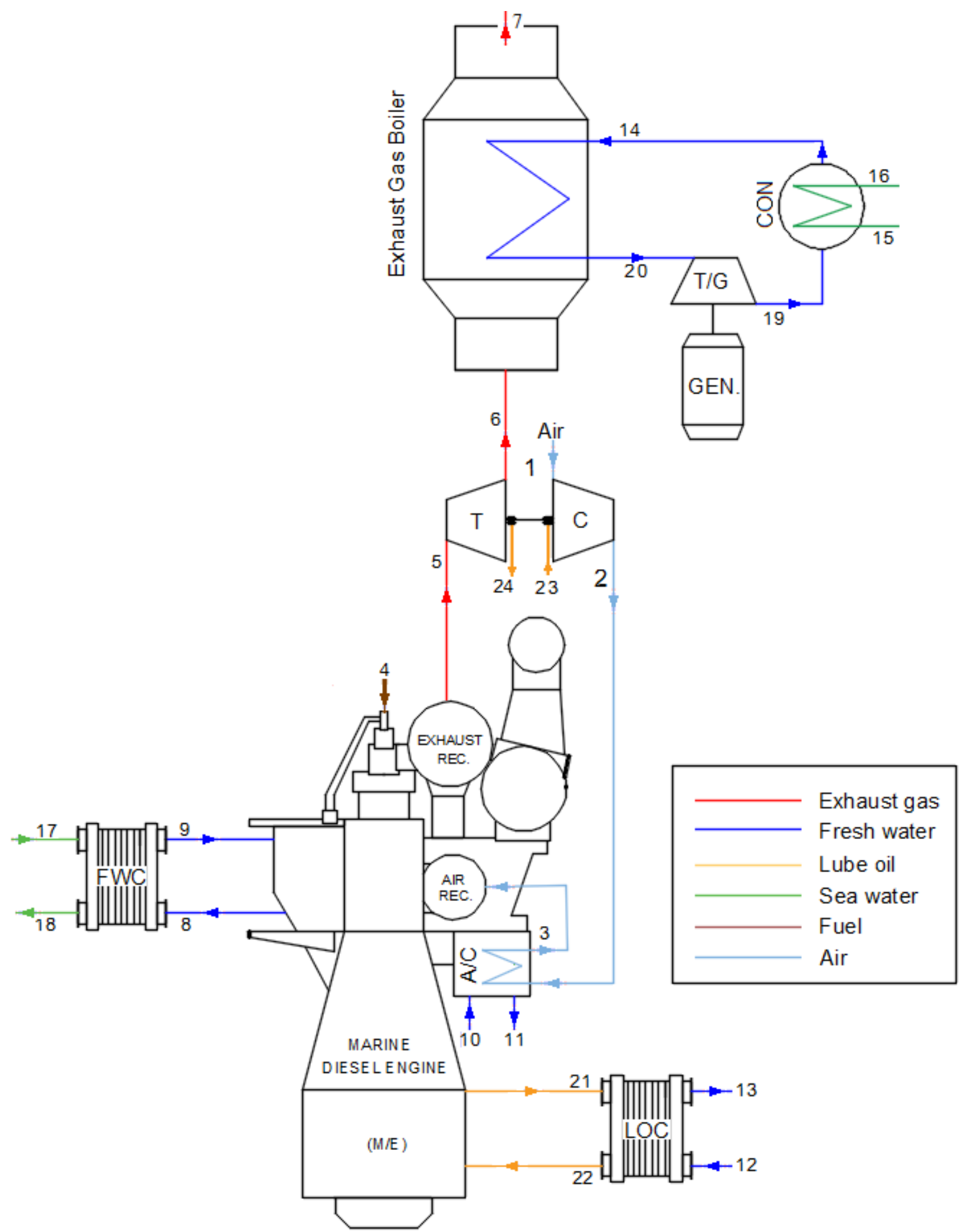

Figure 2. Combined marine power plant and data points.

The data is obtained from 24 state points for exergetic analysis of the combined marine power plant which are shown in Fig.2. This system uses a diesel engine as a primary power system for propulsion of the ship. There are two components for waste heat recovery in the system. These are waste heat boiler (WHR) and three sets of turbo chargers (T/C). The superheated steam produced in the boiler is feeding the turbo generator for electrical power generation. Besides there are auxiliary systems such as lubricating oil cooler (LOC), air cooler (A/C), and fresh water cooler (FWC). The fresh water circulated in FWC is cooled by seawater in a central cooler. Generally, intermediate fuel oil (IFO) or heavy fuel oil (HFO) is used for the main engine of marine power plants. In this 
system, heavy fuel oil is used as fuel for the main diesel engine. In the calculations, the lower heat value of the HFO is taken as $41.80 \mathrm{MJ} / \mathrm{kg}$ [28] . The T/C is cooled by lubricating oil which is also used for bearing lubrication.

The sensor values observed from 24 data points are listed in Table 3. Besides the calculated results of specific exergy $(e)$ and total exergy $(E)$ are shown in the same table. The seawater is the main cooling environment for marine power plants. Therefore, the temperature and salinity are important parameters for calculating the enthalpy, entropy and specific exergy. The salinity and temperature of the seawater is assumed to be $0.3 \%$ and $20^{\circ} \mathrm{C}$, respectively. The specific heat of the lube oil under constant pressure $\left(c_{p, L O}\right)$ which is required for enthalpy, entropy and exergy calculations is calculated from the following equation (Brendel, 1988) [29]:

$$
c_{p, L O}=4.19\left(\frac{0.402+0.00081 T}{\sqrt{d_{15}}}\right)\left(\frac{k J}{k g . K}\right)
$$

where $T$ is temperature of lube oil $\left({ }^{\circ} \mathrm{C}\right), d_{15}$ is the density of lube oil at $15^{\circ} \mathrm{C}\left(\mathrm{g} / \mathrm{cm}^{3}\right)$.

The component based exergy efficiency analysis of the system is carried out based on Fuel and Product exergy principle. The plant consists of nine components which are, exhaust gas turbine (T), air compressor (C), air cooler (AC), main diesel engine (ME), fresh water cooler (FWC), condenser (CON), lube oil cooler (LOC), turbo generator (TG) and

Table 3. Exergy calculations of marine power plant with respect to state points in Fig.2

\begin{tabular}{|c|c|c|c|c|c|c|c|c|}
\hline $\begin{array}{l}\text { State } \\
\text { point }\end{array}$ & $\begin{array}{l}\text { Fluid } \\
\text { type }\end{array}$ & $\underset{(\mathrm{kg} / \mathrm{s})}{\mathrm{m}}$ & $\begin{array}{c}\mathrm{T} \\
\left({ }^{\circ} \mathrm{C}\right)\end{array}$ & $\begin{array}{c}\mathbf{P} \\
\text { (bar) }\end{array}$ & $\begin{array}{c}\mathbf{h} \\
(\mathbf{k J} / \mathbf{k g})\end{array}$ & $\begin{array}{c}\mathrm{S} \\
(\mathrm{kJ} / \mathrm{kg} . \mathrm{K})\end{array}$ & $\begin{array}{c}\mathrm{e} \\
(\mathrm{kJ} / \mathrm{kg})\end{array}$ & $\begin{array}{c}\mathbf{E} \\
(\mathbf{M W})\end{array}$ \\
\hline 0 & Air & - & 30 & 1 & 303.5 & 5.716 & 0 & - \\
\hline 0 & Seawater & - & 20 & 1 & 99.8 & 0.35 & 0 & - \\
\hline 0 & Fresh water & - & 45 & 1 & 125.1 & 0.434 & 0 & - \\
\hline 0 & Fuel oil & - & 45 & 1 & - & - & 0 & - \\
\hline 0 & Lube oil & - & 45 & 1 & - & - & 0 & - \\
\hline 1 & Air & 87 & 45 & 1 & 318.7 & 5.765 & 0 & 0.00 \\
\hline 2 & Air & 87 & 181.2 & 2.92 & 456.3 & 6.817 & 100.9 & 8.78 \\
\hline 3 & Air & 87 & 41 & 2.92 & 314.7 & 5.444 & 98.89 & 8.60 \\
\hline 4 & Fuel oil & 2.16 & 132 & 10.75 & 148.7 & 0.6449 & 42924 & 92.72 \\
\hline 5 & Exhaust gas & 88 & 403 & 2.59 & 415.5 & 6.76 & 279.8 & 24.62 \\
\hline 6 & Exhaust gas & 88 & 272.5 & 2.39 & 303.1 & 6.384 & 196.5 & 17.29 \\
\hline 7 & Exhaust gas & 88 & 163.85 & 1.02 & 185.15 & 7.105 & 146.9 & 12.93 \\
\hline 8 & Fresh water & 113.78 & 85 & 1,94 & 356.2 & 1.134 & 21.49 & 2.45 \\
\hline 9 & Fresh water & 113.78 & 70.1 & 4.28 & 293.8 & 0.9559 & 13.03 & 1.48 \\
\hline 10 & Fresh water & 290 & 32 & 3.67 & 134.4 & 0.4639 & 2.794 & 0.81 \\
\hline 11 & Fresh water & 290 & 42.3 & 2.43 & 177.3 & 0.6028 & 3.658 & 1.06 \\
\hline 12 & Fresh water & 76 & 32 & 3.67 & 134.4 & 0.4639 & 2.794 & 0.21 \\
\hline 13 & Fresh water & 76 & 44 & 2.43 & 184.4 & 0.6253 & 3.953 & 0.30 \\
\hline 14 & Fresh water & 2.32 & 25 & 0.05 & 104.8 & 0.367 & 2.579 & 0.01 \\
\hline 15 & Seawater & 177.70 & 20.00 & 2.57 & 77.81 & 0.2952 & 0.5 & 0.09 \\
\hline 16 & Seawater & 177.70 & 26.68 & 2.57 & 104.1 & 0.3892 & 0.433 & 0.08 \\
\hline 17 & Seawater & 383 & 20 & 3.57 & 77.81 & 0.2952 & 0.5 & 0.19 \\
\hline 18 & Seawater & 383 & 34.4 & 3.57 & 134.5 & 0.4951 & 0.972 & 0.37 \\
\hline 19 & Saturated steam & 2.32 & 31.44 & 0.05 & 2294 & 7.522 & 21.28 & 0.05 \\
\hline 20 & Superheated steam & 2.32 & 265.85 & 8.42 & 2989 & 7.079 & 847.4 & 1.97 \\
\hline 21 & Lube oil & 200.55 & 67 & 6.98 & 67 & 1.454 & 3.78 & 0.76 \\
\hline 22 & Lube oil & 200.55 & 45 & 5.06 & 27.2 & 0.734 & 0.65 & 0.13 \\
\hline 23 & Lube oil & 10.25 & 70 & 4.38 & 72.4 & 1.534 & 4.39 & 0.05 \\
\hline 24 & Lube oil & 10.25 & 74.5 & 4.38 & 80.5 & 1.646 & 5.39 & 0.06 \\
\hline
\end{tabular}


Journal of Thermal Engineering, Research Article, Vol. 5, No. 1, Special Issue 9, pp. 1-13, January, 2019

waste heat boiler for heat recovery (WHR). The exergy equations of each component of combined marine power plant are shown in Table 4.

Table 4. Fuel and Product exergy of components

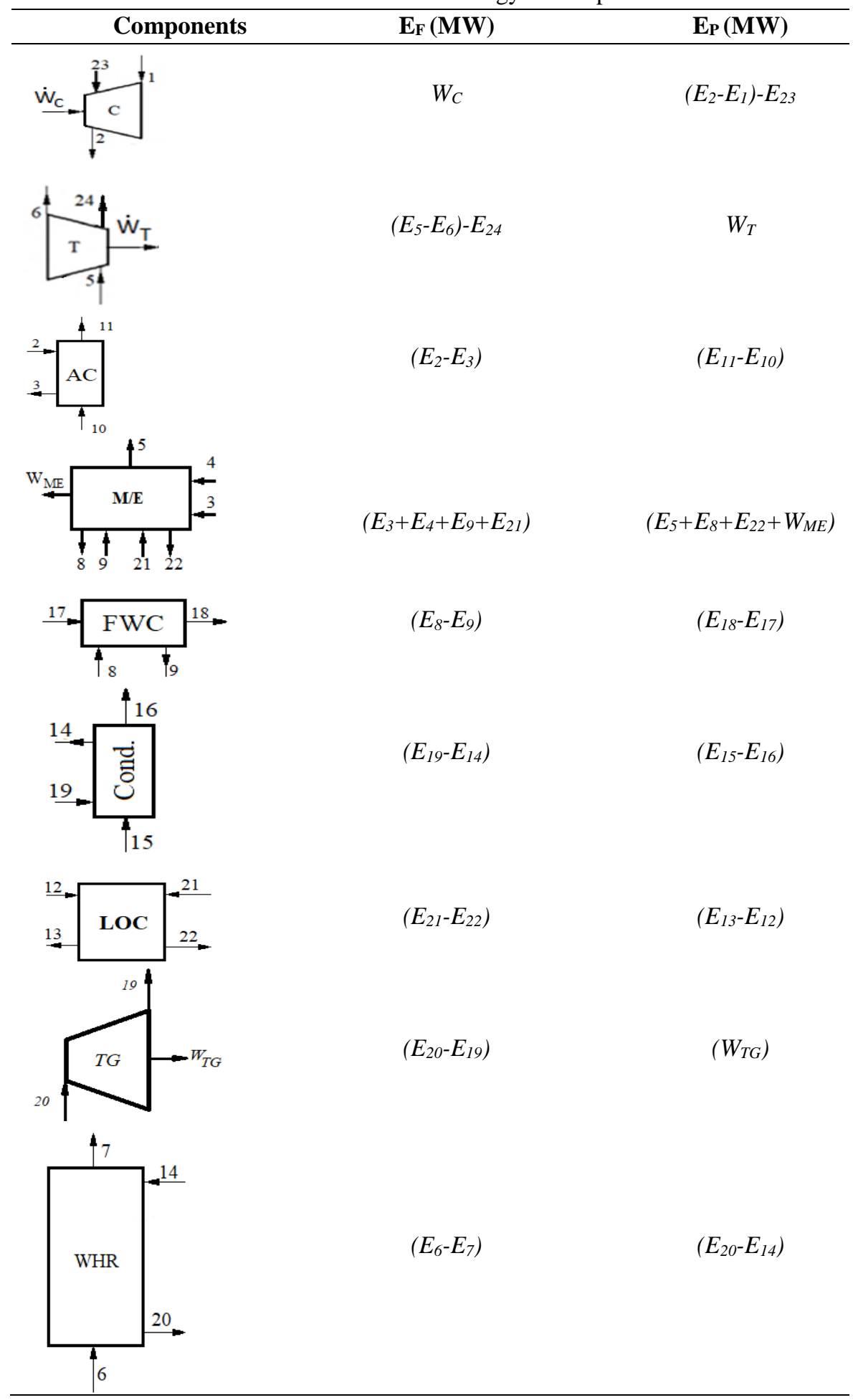




\section{RESULT and DISCUSSION}

The component based exergy calculations are carried out using the equations shown in Table 4. The results of these calculations are listed in Table 5. The exergy destruction ratios $\left(y_{D}\right.$ and $\left.y_{D}^{*}\right)$ and overall system exergy efficiency $(\varepsilon)$ can be seen from this table which is calculated as the ratio which is Ep divided by $\mathrm{E}_{\mathrm{F}}$.

Table 5. Component based exergy outputs of marine power plant

\begin{tabular}{lcccccc}
\hline Components & $\begin{array}{c}\mathbf{E}_{\mathbf{F}} \\
(\mathbf{k W})\end{array}$ & $\begin{array}{c}\mathbf{E P} \\
(\mathbf{k W})\end{array}$ & $\begin{array}{c}\mathbf{E}_{\mathbf{D}} \\
(\mathbf{k W})\end{array}$ & $\begin{array}{c}\mathbf{y}_{\mathbf{D}} \\
(\boldsymbol{\%})\end{array}$ & $\begin{array}{c}\boldsymbol{y}_{\boldsymbol{D}}^{*} \\
(\boldsymbol{\%})\end{array}$ & $\begin{array}{c}\boldsymbol{\varepsilon} \\
(\boldsymbol{\%})\end{array}$ \\
\hline $\mathbf{C}$ & 11971 & 8730 & 3241 & 3.50 & 7.45 & 72.9 \\
$\mathbf{T}$ & 7270 & 9891 & 2621 & 2.83 & 6.02 & 136.1 \\
$\mathbf{A C}$ & 250 & 180 & 70 & 0.08 & 0.16 & 72.0 \\
$\mathbf{M E}$ & 103560 & 70050 & 33510 & 36.14 & 77.02 & 67.6 \\
FWC & 970 & 180 & 790 & 0.85 & 1.82 & 18.6 \\
$\mathbf{C O N}$ & 40 & 10 & 30 & 0.03 & 0.07 & 25.0 \\
LOC & 630 & 90 & 540 & 0.58 & 1.24 & 14.3 \\
TG & 1920 & 1612 & 308 & 0.33 & 0.71 & 84.0 \\
WHR & 4360 & 1960 & 2400 & 2.59 & 5.52 & 45.0 \\
Overall system & 90288 & 44462 & 45826 & 46.93 & 100.00 & 49.20 \\
\hline
\end{tabular}

In the results, it is observed that ME has the greatest fuel exergy value with $103560 \mathrm{~kW}$. However, it has also the greatest exergy destruction value which is $33510 \mathrm{~kW}$ (Figure 3) due to heat loses through exhaust gases, jacket cooling water, and lube oil cooling. As a result, the exergy efficiency of the ME is $67.6 \%$ which is shown in Figure 4. The exergy destruction ratio $\left(\mathrm{y}_{\mathrm{D}}\right)$ value also verify this result.

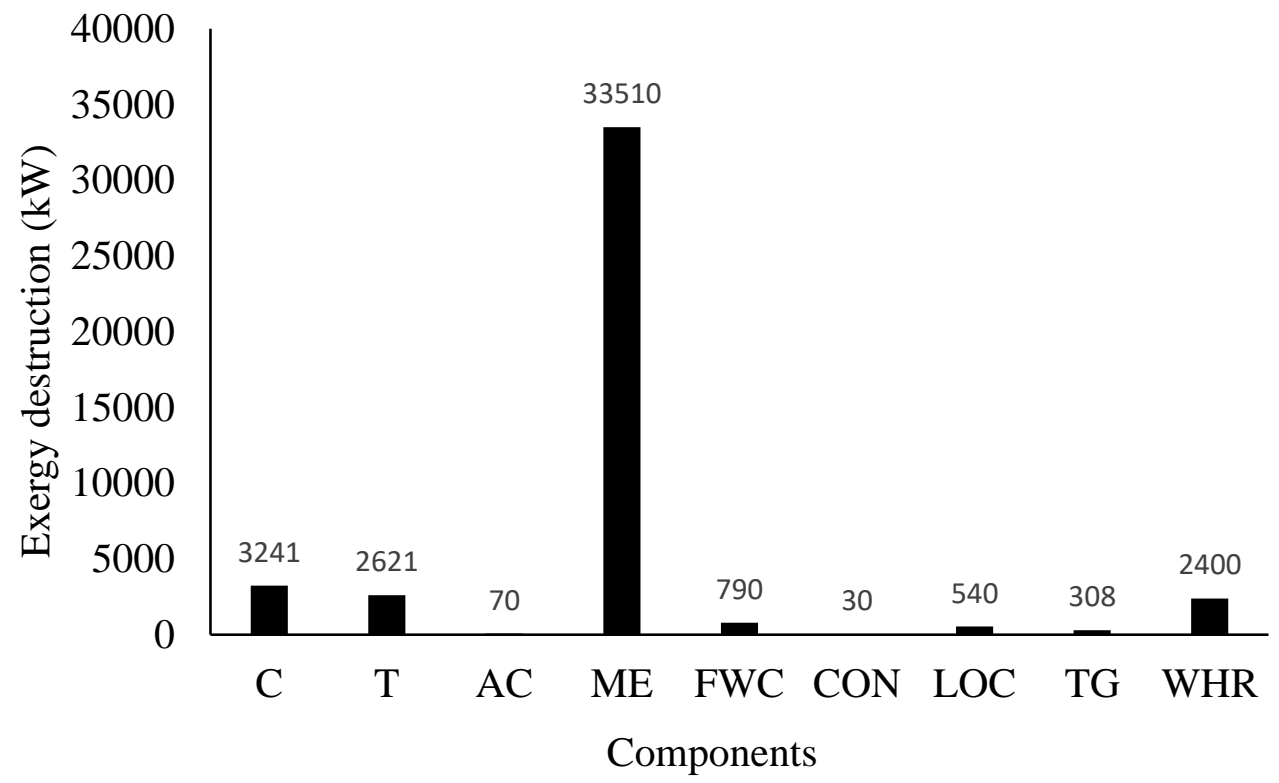

Figure 3. Exergy destructions of components in the combined marine power plant

In the components, TG has the highest exergy efficiency with $84.1 \%$. The highest exergy values after TG are Turbine and Compressor of T/C which are $73.6 \%$ and $73.0 \%$, respectively. The exhaust gas has higher heat energy at T/C. However, it is observed that TG has greater exergy efficiency value than T/C. The main reason of this situation is difference of utilization method of heat energy. T/C uses the velocity of exhaust gases whereas TG uses the heat energy of exhaust gases through WHR. That's why the exergy efficiency of TG is higher. The main reasons for high exergy efficiency values of TG and T/C comparing to other components are high input energy, type of input energy (waste heat), and no external work input to these components. In the components such as 
FWC, CON, and LOC the energy transfer rate is very low due to low temperatures. That is why the exergy efficiency rates are comparatively low. In combined power systems, the significant indicator is overall system exergy efficiency. In this study, the overall system exergy efficiency is reached to $49.2 \%$ which is an acceptable result comparing to studies in the literature.

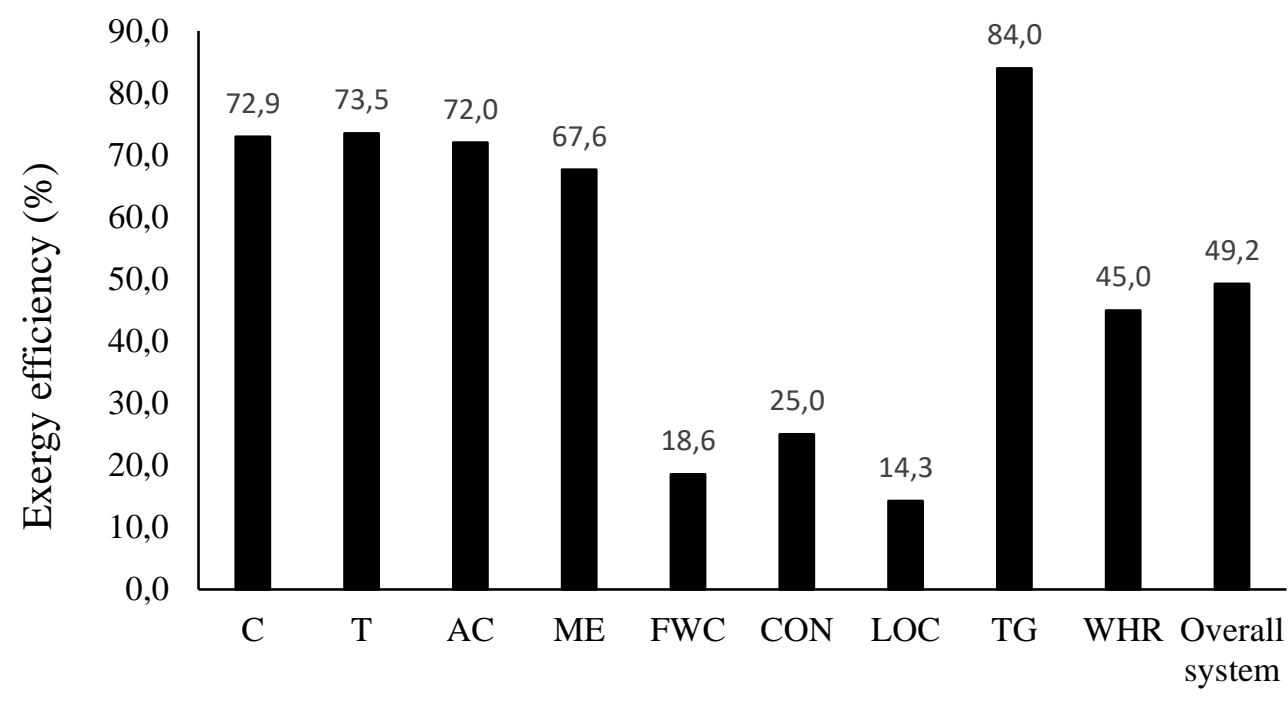

Figure 4. Exergy efficiency of components in the combined marine power plant.

In Figure 5, the exergy values of fuel and product of components and overall system is displayed. Here, ME has the highest fuel and product exergies due to fuel input to the ME and high power output which are 103560 $\mathrm{kW}$ and $70050 \mathrm{~kW}$, respectively. ME is the main component determining the fuel and product exergy of the overall system which can be seen in the figure.

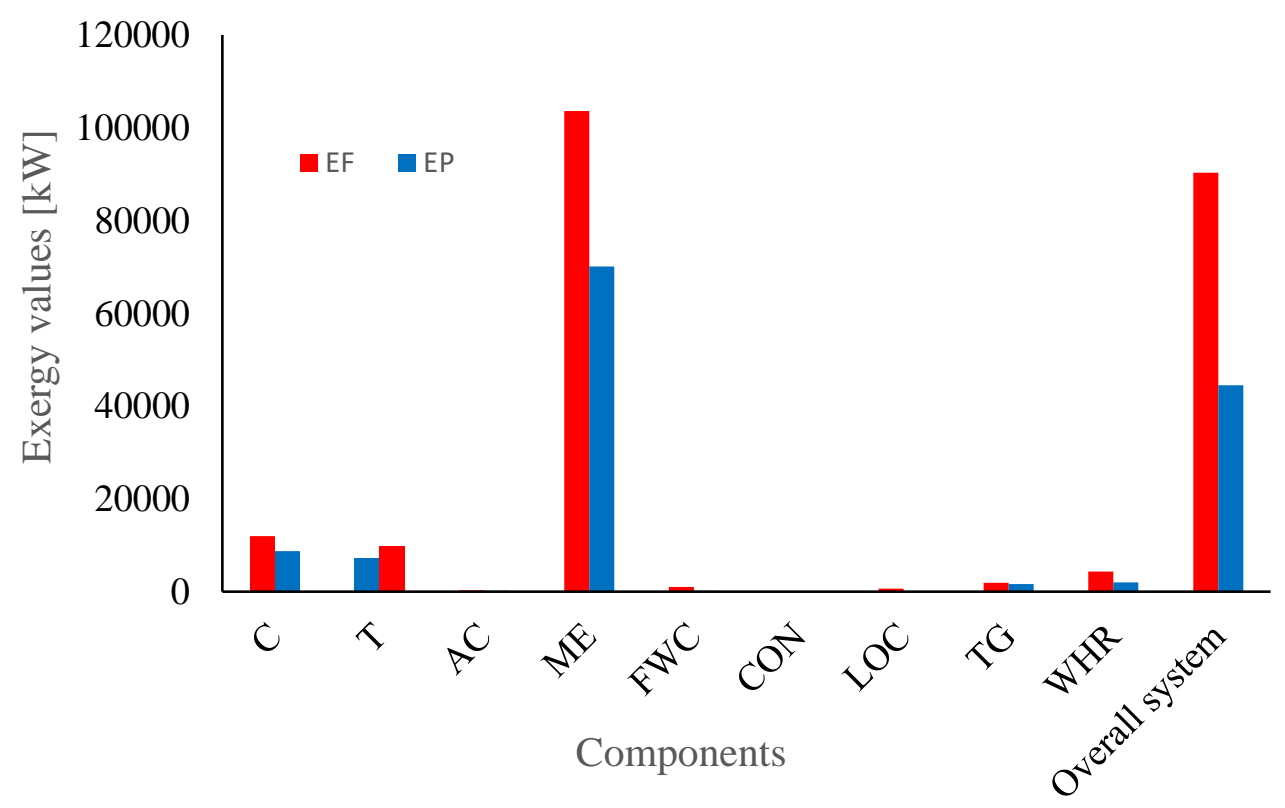

Figure 5. Exergy of fuel and product of components in the combined marine power plant.

In Figure 6, exergy destruction ratios are shown. The ME has highest exergy destruction values as fuel and product exergy values shown before. The main power input to the system is carried out from the engine with high exhaus temperatures and high energy transfers. In ME, the loss energy through various systems such as lubricating oil, jacket cooling water, mechanical friction loses is also higher comparing to other systems. That is why the exergy destruction ratio is higher in ME. 


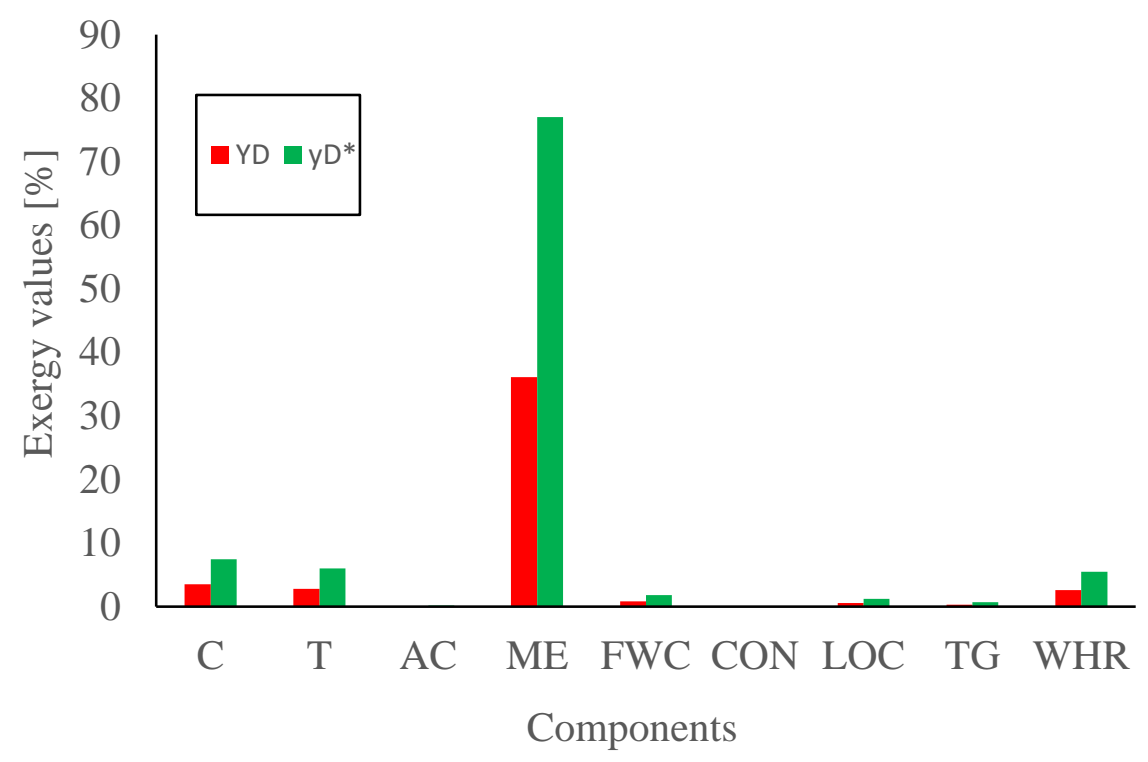

Figure 6. Exergy destruction ratios of components in the combined marine power plant.

\section{CONCLUSION}

In this study, thermodynamic performance analysis of a combined power system of a container ship is carried out by exergy method. The data's used in the calculations are obtained from a realistic full mission engine room simulator. It is assumed that the ship is fully loaded and at full ahead condition. In the analysis, the values of the exergy destruction and exergy values of each component and the overall system are calculated and the results are given as a table. As a result of the analysis, it is found that the largest exergy losses are through the exhaust gases and then in jacket cooling and lubricating oil cooling components, respectively. As a result, it is observed that the application of industrial energy recycling methods to ships increases the exergy efficiency up to $49 \%$. This value is acceptable comparing to similar power plants exergy efficiency values [30]. Exergy efficiency can be further increased by the reduction of thermal losses and the integration of novel technologies. For example, the heat energy released to surrounding by jacket water can be recovered. One of the most studied technologies in recent years is Organic Rankine Cycle (ORC). It seems possible to increase the exergy efficiency by integrating an ORC system to waste heat recovery system of a ship. Furthermore, an absorption chiller can also be installed to decrease lost energy and increase exergy efficiency. These studies are planned as future studies. As a result, it is possible to say that exergy method is a useful in determining the energy losses in marine vessels.

\section{NOMECLATURE}

$\mathrm{A} / \mathrm{C} \quad$ Air Cooler

CC Combined Cycle

CHP Combined Heat And Power

CON Condenser

DEPC Diesel Engine Powered Cogeneration System

EES Engineering Equation Solver

EGT Exhaust Gas Turbine

ERS Engine Room Simulator

FWC Fresh water cooler

GEN Generator

HFO Heavy Fuel Oil

HRSG Heat Recovery Steam Generator

IC Internal Combustion

ICE Internal Combustion Engines

IFO Intermediate Fuel Oil

IMO International Maritime Organization

LOC Lubricating Oil Cooler

M/E Main Engine

MARPOL International Convention for the Prevention of Pollution from Ships 


$\begin{array}{ll}\text { ORC } & \text { Organic Rankine Cycle } \\ \text { ST } & \text { Steam Turbine } \\ \text { T/C } & \text { Turbocharger } \\ \text { T/G } & \text { Turbo-generator } \\ \text { TEG } & \text { Thermoelectric Generators }\end{array}$

\section{REFERENCES}

[1] "IMO", Resolution MEPC.203(62) Amendments to the annex of the protocol of 1997 to amend the international convention, 2011.

[2] Feng, X, Cai, Y.N., Qian, L.L. (1998). A new performance criterion for cogeneration system. Energy Conversion and Management, 39 (15), 1607-1998.

[3] Franco, A., Russo, A. (2002). Combined cycle plant efficiency increase based on the optimization of the heat recovery steam generator operating parameters, International Journal of Thermal Sciences, 41, 843-859.

[4] Yilmaz T, (2004). Optimization of cogeneration systems under alternative performance criteria, Energy Conversion and Management, 45 (6), 939-945.

[5] Danov, S. N., Gupta, A. K. (2004). Modeling the performance characteristics of diesel engine based combinedcycle power plants-Part I: Mathematical Model. Journal of Engineering for Gas Turbine and Power, 126, 28-34.

[6] Danov, S. N., Gupta, A. K. (2004). Modeling the performance characteristics of diesel engine based combinedcycle power plants-Part II: Results and Applications. Journal of Engineering for Gas Turbine and Power, 126, 3539.

[7] Tien, W.K., Yeh, R.H., Hong, J.M. (2007). Theoretical analysis of cogeneration system for ships. Energy Conversion and Management, 48, 1965-1974.

[8] Ebadi, M. J., Bandpy, M. G. (2005). Exergetic analysis of gas turbine plants. International Journal of Exergy, 2 (1), 31-39.

[9] Kamate, S. C., Gangavati, P. B. (2008). Exergetic, thermal, and fuel savings analyses of a $20.70 \mathrm{MW}$ bagassebased cogeneration plant. Cogeneration\&Distributed Generation Journal, 23(3), 45-58.

[10] Abusoglu, A., Kanoglu, M. (2009). Exergetic and thermoeconomic analyses of diesel engine powered cogeneration: Part 1 - Formulations, Applied Thermal Engineering 29, 234-241.

[11] Abusoglu, A., Kanoglu, M. (2009). Exergetic and thermoeconomic analyses of diesel engine powered cogeneration: Part 2 - Applications, Applied Thermal Engineering 29, 242-249.

[12] MAN Diesel \& Turbo. Waste heat recovery system (WHRS) for reduction of fuel consumption, emissions and EEDI. Copenhagen, Denmark; 2012

[13] Saidur, R., Rezaei, M., Muzammil, W. K., Hassan, M. H., Paria, S., Hasanuzzaman, M. (2012). Technologies to recover exhaust heat from internal combustion engines. Renewable and Sustainable Energy Reviews, 16(8), 5649-5659.

[14] Shu, G., Liang, Y., Wei, H., Tian, H., Zhao, J., Liu, L. (2013). A review of waste heat recovery on two-stroke IC engine aboard ships. Renewable and Sustainable Energy Reviews, 19, 385-401.

[15] Grljušić, M., Medica, V., Račić, N. (2014). Thermodynamic analysis of a ship power plant operating with waste heat recovery through combined heat and power production, Energies 7,7368-7394.

[16] Man B\&W Diesel A/S. 2007. Thermo efficiency system (TES) for reduction of fuel consumption and CO2 emission. MAN Diesel brochure, Denmark.

[17] Baldi F, Gabrielii, C. (2015). A feasibility analysis of waste heat recovery systems for marine applications. Energy 80:654-65.

[18] Seyyedvalilu, M. H., Mohammadkhani, F., Khalilarya, S. (2015). A parametric study on exergy and exergoeconomic analysis of a diesel engine based combined heat and power system, International Journal of Engineering (IJE), TRANSACTIONS A: Basics 28 (4), 608-617.

[19] Benvenuto G., Trucco, A., Campora, U. (2016). Optimization of waste heat recovery from the exhaust gas of marine diesel engines. Proceedings of the Institution of Mechanical Engineers, Part M: Journal of Engineering for the Maritime Environment, 230(1), 83-94.

[20] Marty, P., Hétet, J. F., Chalet, D., Corrignan, P. (2016). Exergy analysis of complex ship energy systems. Entropy, 18(4), 127.

[21] Baldi, F., Ahlgren, F., Nguyen, T-V., Gabrielii, C., Andersson, K. (2015). Energy and exergy analysis of a cruise ship. In Proceedings of ECOS 2015: 28th International Conference on Efficiency, Cost, Optimization, Simulation and Environmental Impact of Energy Systems.

[22] Baldi, F., Johnson, H., Gabrielii, C., \& Andersson, K. (2015). Energy and exergy analysis of ship energy systems-the case study of a chemical tanker. International Journal of Thermodynamics, 18(2), 82-93.

[23] Singh, D. V., Pedersen, E. (2016). A review of waste heat recovery technologies for maritime applications. Energy conversion and management, 111, 315-328.

[24] Kotas T.J. The exergy method of thermal plant analysis. Great Britain: Anchor Brendon Ltd, 1985. 
Journal of Thermal Engineering, Research Article, Vol. 5, No. 1, Special Issue 9, pp. 1-13, January, 2019

[25] Ameri, M., Ahmadi, P. (2007). The study of ambient temperature effects on exergy losses of a heat recovery steam generator, in: Proceedings of the 15th international conference on Mechanical Engineering, no.2053, Tehran,Iran, 2007.

[26] Bejan, A., Tsatsaronis, G., Moran, M, Thermal design and Optimization, Wiley, New York, 1996.

[27] C. A. Frangopolous, Exergy, Energy System Analysis and Optimization, Eolss Publishers Co. Ltd., OxfordUnited Kingdom, 2009.

[28] http://www.globalcombustion.com/oil-fuel-properties/

[29] Brendel H. (1988). Schmierstoffe, Wissensspeicher Tribotechnik, VEB Fachbuchverlag, Leipzig.

[30] Kanoglu, M., Dincer, I. (2009). Performance assessment of cogeneration plants. energy conversion and management, 50(1), 76-81. 